\title{
Akuntabilitas, Transparansi, Partisipasi Masyarakat dan Pengelolaan Alokasi Dana Desa Untuk Meningkatkan Good Village Governace
}

\author{
Moh Syamsul Rijal ${ }^{1}$ \\ Fakultas Ekonomi dan Bisnis \\ Universitas Mataram, Indonesia
}

\author{
Lilik Handajani² \\ Fakultas Ekonomi dan Bisnis \\ Universitas Mataram, Indonesia
}

\section{Dwi Putra Buana Sakti ${ }^{3}$ \\ Fakultas Ekonomi dan Bisnis \\ Universitas Mataram, Indonesia}

\begin{abstract}
Surel: rijalr84@gmail.com
ABSTRAK

Penelitian bertujuan untuk menganalisis pengaruh Akuntabilitas, Transparansi dan Partispasi Masyarakat terhadap pengelolaan Alokasi Dana Desa (ADD) untuk meningkatkan Good Village Governace (GVG) yang ada di Lombok Barat. Sampel responden ditetapkan secara non probability sampling yaitu purposive sampling Jumlah responden 108 orang yang menjabat sebagai Kepala Desa, Sekretaris Desa, Bendahara Desa, dan Masyarakat. Pengumpulan data dilakukan dengan Kuisioner. Teknik analisis dilakukan dengan menggunakan model analisis regresi linear berganda. Hasil penelitian akuntabilitas berpengaruh positif dan signifikan terhadap pengelolaan alokasi dana desa, sama halnya dengan transparansi berpengaruh positif dan signifikan terhadap pengelolaan alokasi dana desa. Berbeda dengan hasil dari partisipasi masyarakat berpengaruh positif dan tidak signifikan terhadap pengelolaan alokasi dana desa. Implikasi praktis hasil penelitian bagi aparatur pemerintah desa dan kepala desa di Kabupaten Lombok Barat untuk terciptanya pengelolaan alokasi dana desa yang sehat. Selain itu, terbentuknya desa mandiri dengan menambah pendapatan asli desa, keterbukaan anggaran, akuntabilitas dan transparansi.
\end{abstract}

Kata Kunci: Akuntabilitas,Transparansi,Partisipasi masyarakat, pengelolaan alokasi dana desa

\section{Accountability, Transparency, Community Participation and Management of Village Fund Allocations to Improve Good Village Governace}

\section{ABSTRACT}

This study aims to analyze the effect of Accountability, Transparency and Community Participation on the management of Village Fund Allocation (ADD) to improve Good Village Governance (GVG) in West Lombok. The sample of respondents was determined by nonprobability sampling, namely purposive sampling. The number of respondents was 108 people who served as Village Head, Village Secretary, Village Treasurer, and Community. Data collection is done by questionnaire. The analysis technique is done by using multiple linear regression analysis model. The results of the accountability research have a positive and significanteffect on the management of village fund allocations, as well as transparency has a positive and significant effect on the management of village fund allocations. In contrast, the results of community participation have a positive and insignificant effect on the management of village fund allocations. Practical implications of the research results forvillage government officials and village heads in West Lombok Regency for the creation of a healthy village fund allocation management. In addition, the formation of an independent village by increasing the village's original income, budget transparency, accountability and transparency.

Keywords: $\quad$ Accountability, Transparency, Community Participation, Management Of Village Fund Allocation.

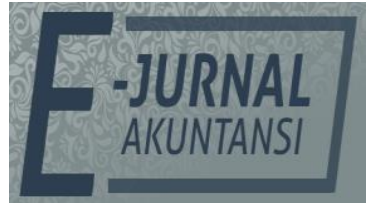

e-ISSN 2302-8556

Vol. 31 No. 12

Denpasar, Desember 2021

Hal. 3301-3313

DOI:

10.24843/EJA.2021.v31.i12.

PENGUTIPAN:

Rijal, M. S., Handjani, L. \& Sakti, D. P. B. (2021).

Akuntabilitas,

Transparansi, Partisipasi

Masyarakat dan

Pengelolaan Alokasi Dana

Desa Untuk

Meningkatkan Good

Village Governace. E-Jurnal

Akuntansi, 31(12), 3301-3313

RIWAYAT ARTIKEL:

Artikel Masuk:

20 November 2021 Artikel Diterima: 24 Desember 2021

Artikel dapatdiakses: https:/ / ojs.unud.ac.id/index.php/Akuntansi/index 


\section{PENDAHULUAN}

Undang-Undang Desa 6 Tahun 2014 telah menempatkan desa sebagai ujung tombak pembangunan dan peningkatan kesejahteraan masyarakat. Desa diberikan kewenangan dan sumber dana yang memadai agar dapat mengelola potensi yang dimilikinya guna meningkatkan ekonomi dan kesejahtaraan masyarakat (Republik Indonesia, 2014). Setiap tahun Pemerintah Pusat telah menganggarkan Alokasi Dana Desa yang cukup besar untuk diberikan kepada Desa. Pemerintah sedang mengupayakan peningkatan pelaksanaan Pembangunan Nasional agar antara laju pembangunan kota dan desa semakin seimbang dan serasi. Tetapi dalam pembangunan masih dihadapakan pada persoalan seperti ketimpangan atau ketidak merataan pembangun anantara kota dan desa. Pembangunan desa mempunyai peran yang sangat penting dalam rangka Pembangunan Nasional dan Pembangunan Daerah karena terkandung unsur pemerataan pembangunan dan hasil-hasilnya serta menyentuh secara langsung kepentingan masyarakat desa dalam upaya meningkatkan kesejahteraan mereka(Putra et al., 2013). Berdasarkan UU Nomor 6 Tahun 2014 tentang Desa, diharapkan segala kepentingan dan kebutuhan masyarakat desa dapat diakomodir dengan lebih baik. Pemberian kesempatan yang lebih besar bagi desa untuk mengurus tata pemerintahannya sendiri serta pemerataan pelaksanaan pembangunan diharapkan dapat meningkatkan kesejahteraan dan kualitas hidup masyarakat desa, sehingga permasalahan seperti kesenjangan antar wilayah, kemiskinan, dan masalah sosial budaya lainnya dapat diminimalisir (Rakyat \& Presiden, 2014).

Sejak tahun 2015, Dana Desa dianggarkan sebesar Rp20,7 triliun, dengan rata-rata setiap desa mendapatkan alokasi sebesar Rp280 juta. Pada tahun 2016, Dana Desa meningkat menjadi Rp46,98 triliun dengan rata-rata setiap desa sebesar Rp 628 juta dan di tahun 2017 kembali meningkat menjadi Rp 60 Triliun dengan rata-rata setiap desa sebesar Rp 800 juta (Kementrian Keuangan, 2017). Angaran Pendapatan Belanja Negara-Pemerintah (APBN-P) tahun 2015 telah dialokasikan Dana Desa sebesar \pm Rp 20,776 triliun kepada seluruh desa yang tersebar di Indonesia. Jumlah desa yang ada saat ini sesuai Permendagri 39 Tahun 2015 sebanyak 74.093 desa. Selain Dana Desa, sesuai UU Desa pasal 72, Desa memiliki Pendapatan Asli Desa dan Pendapatan Transfer berupa Alokasi Dana Desa; Bagian dari Hasil Pajak dan Retribusi Kabupaten/Kota; dan Bantuan Keuangan dari APBD Provinsi/ Kabupaten/Kota. Sejak awal dialokasikannya dana desa, anggaran untuk dana desa tersebut selalu mengalami kenaikan. Berikut perbandingan anggaran dana desa tahu 2015 sampai 2019 (Kementrian Keuangan, 2020).

Tabel 1. Jumlah Angaran Dana Desa tahun 2015-2019

\begin{tabular}{cc}
\hline Tahun & Jumlah Anggaran (Triliun) \\
\hline 2015 & 20,7 \\
2016 & 47 \\
2017 & 50 \\
2018 & 60 \\
2019 & 70 \\
\hline
\end{tabular}

Sumber: Kementrian Keuangan, 2020 
Dengan adanya kenaikan alokasi dari dana desa tersebut, tentunya membawa pengaruh positif terhadap desa, diantaranya seperti tersedianya infrastruktur desa yang memadai seperti adanya pembangunan jalan desa, adanya penyediaan pos kesehatan di desa, dan sebagainya. Akan tetapi, capaian dan dampak positif tersebut juga membawa permasalahan dan tantangan yang muncul serta menjadi pokok permasalahan yang serius. Permasalahan tersebut muncul dari adanya anggaran desa yang besar, akan tetapi tidak diiringi dengan adanya kemampuan untuk mengelola keuangan dengan baik dan benar. Peran besar yang diterima oleh desa, tentunya disertai dengan tanggung jawab yang besar pula. Oleh karena itu pemerintah desa harus bisa menerapkan prinsip akuntabilitas dalam tata pemerintahannya, dimana semua akhir kegiatan penyelenggaraan pemerintahan desa harus dapat dipertanggungjawabkan kepada masyarakat desa sesuai dengan ketentuan.

Berkaitan Agency theory yang menyatakan bahwa Teori keagenan mendeskripsikan hubungan antara pemegang saham (shareholders) sebagai prinsipal dan manajemen sebagai agen. Manajemen sebagai pihak yang dikontrak oleh pemegang saham untuk bekerja demi kepentingan pemegang saham. Penggunaan teori keagenan telah dipergunakan secara luas baik disektor privat maupun sektor publik. Para ekonom menggunakan struktur hubungan prinsipal dan agen untuk menganalisa hubungan antara perusahaan dengan pekerja (Faria \& Maria, 2013). Teori keagenan telah dipraktekkan pada sektor publik khususnya pemerintah pusat maupun daerah. Pemerintah sebagai pricipal wajib Organisasi sektor publik bertujuan untuk memberikan pelayanan maksimal kepada masyarakat atas sumber daya yang digunakan untuk memenuhi hajat hidup orang banyak. Pemerintah tidak dapatmelakukan pengelolaan dan pengalokasian sumber daya secara sendirian, sehingga pemerintah memberikan wewenang kepada pihak lain untuk mengelola sumber daya. Pembuatan anggaran menjadi mekanisme yang penting untuk alokasi sumber daya karena adanya keterbatasan dana yang dimiliki pemerintah.

Salah satu faktor yang mempengaruhi pengelolaan dana desa yaitu transparansi. Transparansi adalah prinsip untuk membuka diri kepada hak masyarakatsebagai upaya untuk perolehan akses informasi yang benar, jujur, dan tidak diskriminatif mengenai penyelenggaraan organisasi dengan memperhatikan perlindungan atas hak asasi pribadi, golongan, dan rahasia negara. Dalam pengelolaan alokasi dana desa, transparansi ini dimaksudkan agar aparat desa bertindak dan/atau berperilaku sesuai dengan aturan hukum dan etika yang berlaku, dan juga sesuai dengan amanat yang diberikan masyarakat dalam pengelolaan alokasi dana desa. Dengan kata lain, transparansi ini dilakukan untuk memberikan penjelasan maupun pertanggungjawaban kepada masyarakat mengenai program dan kebijakan yang telah dilakukan dan/atau sedang dilakukan beserta sumber daya yang digunakan(Nur, 2019).

Akuntabilitas merupakan pertanggungjawaban kepada publik yang dalam hal ini adalah masyarakat atas setiap aktivitas yang telah dilakukan (Madiasmo, 2018). Akuntabilitas merupakan suatu bentuk pertanggungjawaban dari pihak yang diberi kepercayaan oleh stakeholders dimana nantinya akan menghasilkan keberhasilan atau kegagalan dalam pelaksanaan tugasnya untuk mencapai tujuan yang telah ditetapkan. Akuntabilitas dalam pengelolaan dana desa mempunyai 
tujuan untuk meningkatkan kinerja pemerintahan desa dengan tugas-tugas yang telah dibebankan untuk meningkatkan nilai dan kualitas kegiatan pelayanan kepada masyarakat. Dengan adanya akuntabilitas ini, kinerja pemerintah desa dalam pelaksanaan tugas dan fungsinya akan terukur. Kinerja suatu organisasi dapat terlihat dari sisi pertanggungjawaban, seperti dalam pengelolaan dana, program kerja yang telah tersusun, maupun kebijakan lain yang telah ditetapkan. Oleh karena itu, dengan adanya akuntabilitas ini akan mengungkapkan segala bentuk penyelewengan wewenang yang dapat diawasi dan dikontrol oleh masyarakat (Mardiasmo, 2009).

Asas selanjutnya adalah asas partisipasi, yaitu keterlibatan masyarakat dalam pembuatan keputusan, baik secara langsung maupun tidak langsung melalui lembaga perwakilan masyarakat untuk menyampaikan aspirasinya. Dalam pengelolaan keuangan desa, keterlibatan masyarakat sangat penting dilakukan, keterlibatan tersebut dimulai dari perencanaan, penganggaran, hingga pelaksanaan(Ultafiah, 2017). Akan tetapi, masyarakat saat ini banyak yang belum memahami, bahkan belum mengerti mengenai alokasi dana desa. Berkaitan dengan asas-asas pengelolaan keuangan desa tersebut, pemberdayaan masyarakat menjadi tugas utama pemerintahan desa. Dengan adanya masyarakat yang berdaya, diharapkan akan meningkatkan pendapatan desa yang secara otomatis akan meningkatkan kesejahteraan masyarakat. Pemberdayaan masyarakat dimaksudkan sebagai proses pengembangan, memandirikan, menswadayakan, dan memperkuat posisi tawar menawar masyarakat lapisan bawah terhadap kekuatan-kekuatan yang menekan di segala bidang dan sektor kehidupan. Pemberdayaan masyarakat penting dilakukan agar masyarakat lebih proaktif dan tanggap terhadap potensi yang dimiliki daerah dan/atau desa tersebut. Sehingga, alokasi anggaran dapat terserap dengan optimal dan lebih bermanfaat dalam pengembangan desa, bahkan daerah dan negara(Kementrian Keuangan, 2017).

Garung \& Ga (2020) menyatakan bahwa akutabilitas berpengaruh secara simultan terhadap pengelolaan alokasi dana desa. Penelitian (Sukmawati \& Nurfitriani, 2019) bahwa akuntanbilitas berpengaruh terhadap pengelolaan keuangan desa. Penelitian yang dilakukan oleh (Umami \& Nurodin, 2017) serta (Sirajudin, 2019) menyatakan bahwa akuntanbilitas berpengaruh signifikan terhadap pengelolaan keuangan Alokasi dana desa. Namun tidak sejalan dengan penelitian yang dilakukan oleh (Fahri, 2020) menyimpulkan bahwa akuntabilitas tidak berpengaruh singnifikan terhadap pengelolaan keuangan alokasi dana desa.

Penelitian Garung \& Ga (2020) menyatakan bahwa transparansi berpengaruh secara simultan terhadap pengelolaan alokasi dana desa. Sejalan dengan penelitian (Andriani, 2019) menyimpulkan bahwa transparansi berpengaruh terhadap pengelolaan alokasi dana desa. Penelitian (Firdaus, 2020) menyatakan bahwa varibel transparansi berpengaruh positif singnifikan terhhadap pengelolaan alokasi dana desa. Selain itu (Damayanti, 2018) menyimpulkan bahwa transparansi berpengaruh terhadap alokasi dana desa di desa Tegiri. Namun hasil penelitian (Damayanti, 2018) bahwa transparansi tidak berpengaruh terhadap pengelolaan alokasi desa dasa di Desa Sumberagung. Didukung oleh (Sukmawati \& Nurfitriani, 2019) menyimpulkan bahwa transparansi tidak berpengaruh terhadap pengelolaan keuangan desa. 
Penelitian yang dilakukan (Firdaus, 2020) menyimpulkan bahwa partisipasi masyarakat berpengaruh terhadap pengelolan alokasi dana desa. Sejalan denngan (Andriani, 2019) bahwa variabel partisipasi masyarakat berpengaruh singnifikan terhadap pnegelolaan alokasi dana desa. Berdasarkan hasil penelitian yang berbeda menunjukan adanya ketidakkonsistenan antara penelitian-penelitian sebelumnya. Hasil penelitian di berbagai Desa bahkan belum dapat menegaskan bahwa variabel akuntanbiltas, tranparasi dan par tisipasi masyarakat berpengaruh positif signifikan terhadap pengelolaan alokasi dana desa. Penelitian ini akan dilakukan pada desa desa yang ada di kecamatan Labuapi dan Kecamatan Lingsar Kabupaten Lombok Barat.

Akuntabilitas merupakan suatu upaya untuk memberikan pertanggungjawaban mengenai segala aktivitas dan kinerja yang telah dilakukan oleh suatu entitas kepada pihak-pihak yang berkpentingan. Akuntabiltas adalah pertanggungjawaban kepada publik atas setiap aktivitas yang dilakukan. Akuntabilitas publik adalah kewajiban pihak pemegang amanah (agent) untuk memberikan pertanggungjawaban, menyajikan, melaporkan, dan mengungkapkan segala aktivitas dan kegiatan yang menjadi tanggungjawabnya kepada pihak pemberi amanah (principal) yang memiliki hak dan kewenangan untuk meminta pertanggungjawaban tersebut (Mahmudi, 2015). Garung dan linda (2020) menyatakan bahwa akutabilitas berpengaruh secara simultan terhadap pengelolaan alokasi dana desa. Penelitian (Sukmawati \& Nurfitriani, 2019) bahwa akuntanbilitas berpengaruh terhadap pengelolaan keuangan desa. Penelitian yang dilakukan oleh (Umami \& Nurodin, 2017) serta (Sirajudin, 2019) menyatakan bahwa akuntanbilitas berpengaruh signifikan terhadap pengelolaan keuangan alokasi dana desa. Namun tidak sejalan dengan penelitian yang dilakukan oleh (Fahri, 2020) menyimpulkan bahwa akuntabilitas tidak berpengaruh singnifikan terhadap pengelolaan keuangan alokasi dana desa. Hal ini menegaskan bahwa, dengan dilaksanakannya akuntabilitas dalam mengelola alokasi dana desa oleh aparatur desa, maka penulis mengajukan hipotesis bahwa akuntabilitas berpengaruh terhadap pengelolaan alokasi dana desa.

$\mathrm{H}_{1}$ : Akuntabilitas berpegaruh positif terhadap pengelolaan alokasi dana desa untuk mewujudkan Good Vilage Governance.

Transparansi adalah prinsip yang menjamin akses atau kebebasan bagi setiap orang untuk memperoleh informasi tentang penyelenggaraan pemerintahan, yakni informasi tentang kebijakan, proses pembuatan dan pelaksanaannya, serta hasil-hasil yang dicapai. Transparansi yakni adanya kebijakan terbuka bagi pengawasan, sedangkan yang dimaksud dengan informasi adalah informasi mengenai setiap aspek kebijakan pemerintah yang dapat dijangkau oleh publik. Upaya dalam meningkatkan pengelolaan Alokasi Dana Desa harus terbuka atas semua informasi yang didapat serta melibatkan masyarakat. Keterbukaan atau informasi yang didapat dan keterlibatan publik dalam pengelolaan Alokasi Dana Desa adalah awal perencanaan penyusunan Dana Desa melalui musyawarah rencana pembangunan (musrenbang) pada berbagai tingkat. Pada saat musyawarah rencana pembangunan usulan pembangunan adalah berdasarkan pada skala prioritas yang langsung diusulkan oleh publik. Pelaksanaan dari musyawarah rencana pembangunan yang sudah disusun berdasarkan skala prioritas harus sesuai dengan usulan pada saat 
musyawarah rencana pembangunan. Semakin transparan pemerintah terhadap perencanaan pembangunan dan pengelolaan keuangan, maka semakin mudah untuk mewujudkan Good Village Governance(Madiasmo, 2018).

Penelitian (Garung \& Ga, 2020) menyatakan bahwa transparansi berpengaruh secara simultan terhadap pengelolaan alokasi dana desa. Sejalan dengan penelitian (Andriani, 2019) menyimpulkan bahwa transparansi berpengaruh terhadap pengelolaan alokasi dana desa. Penelitian (Firdaus, 2020) menyatakan bahwa varibel transparansi berpengaruh positif singnifikan terhhadap pengelolaan alokasi dana desa. Selain itu (Damayanti, 2018) menyimpulkan bahwa transparansi berpengaruh terhadap alokasi dana desa di desa Tegiri. Namun hasil penelitian (Damayanti, 2018) bahwa transparansi tidak berpengaruh terhadap pengelolaan alokasi desa dasa di Desa Sumberagung. Didukung oleh (Sukmawati \& Nurfitriani, 2019) menyimpulkan bahwa transparansi tidak berpengaruh terhadap pengelolaan keuangan desa. Maka hipotesis yang dapat dirumuskan adalah sebagai berikut.

$\mathrm{H}_{2}$ : Transparansi berpengaruh Posisituf terhadap pengelolaan alokasi dana desa untuk mewujudkan Good Vilage Governance.

Partisipasi dibangun atas kebebasan berasosiasi dan berbicara (Mardiasmo, 2009) Partisipasi yang berarti setiap orang atau warga negara masyarakat, baik laki-laki maupun perempuan memiliki hak suara yang sama dalam proses pengambilan keputusan, baik secara langsung maupim lembaga perwakilan, sesuai dengan kepentingan dan aspirasinya masingmasing (UNDP). Partisipasi adalah peran serta seseorang atau kelompok masyarakat daiam proses pembangunan baik dalam bentuk pemyataan maupun daiam bentuk kegiatan dengan memberi masukan pikiran. tenaga, waktu, keahlian, modal dan atau materi, serta ikut memanfaatkan dan menikmati hasil-hasil pembangunan (Sumaryadi, 2010: 46).

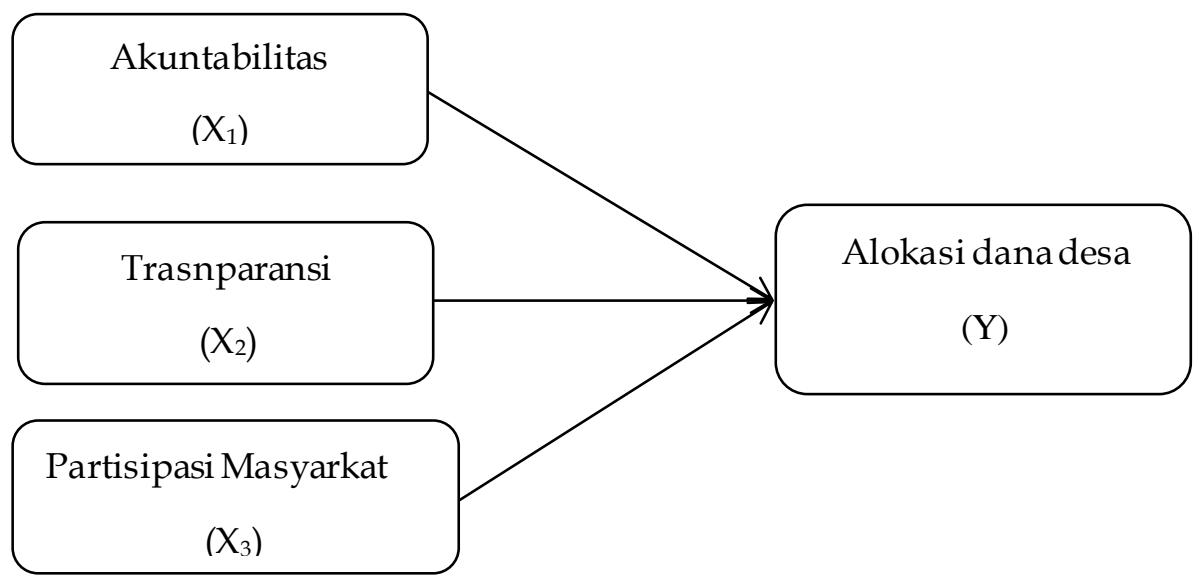

Sumber: Data Penelitian

\section{METODE PENELITIAN}

Jenis penelitian ini merupakan penelitian eksplanatori dengan pendekatan kuantitatif. Penelitian ini dilakukan di desa-desa wilayah Kecamatan Labu Api dan Kecamatan Lingsar, Kabupaten Lombok Barat. Pemilihan lokasi ini dengan 
pertimbangan karena pernah terjadinya kasus penyalah gunaan alokasi dana desa di salah satu desa yang ada di Kecamatan Labu Api yaitu Desa Terong Tawah(Inside, 2020) dan Masalah Sumbagan PDAM yang terjadi di Kecamatan Lingsar. Populasi dalam penelitian ini yaitu seluruh desa yang ada di Kecamatan Labu Api, dan Kecamatan Lingsar Kabupaten Lombok Barat. Berdasarkan data yang diperoleh jumlah desa di Kecamatan Labu Api yaitu sebanyak 12 desa dan Kecamatan Lingsar sebanyak 15 Desa total desa yaitu 27. Penelitian akan mengambil 4 orang setiap desa untuk dijadikan responden, antara lain: Kepala Desa, Sekretaris Desa, Bendahara, Masyarkat total responden 108. Responden Pengujian hipotesis penelitian dilakukan dengan menggunakan model analisis Regresi Linear Berganda.

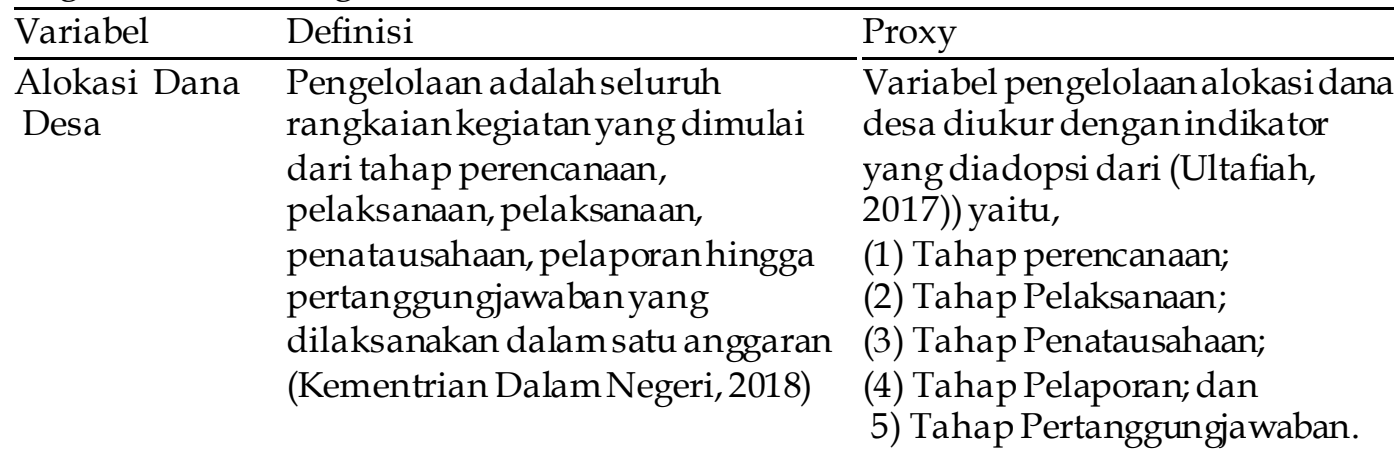

Akuntabilitas kewajiban pihak pemegang amanah Akuntabilitas diukur dengan unutk memberikan menggunakan 5 indikator yaitu: pertanggungjawaban, menyajikan, (1) akuntabilitas kejujuran dan melaporkan danmengungkapkan hukum; segala aktivitas dan kegiatan yang (2) akuntabilitas manajerial; menjadi tanggungjawabnya kepada (3) akuntabilitas program; pihak pemberi amanahyang (4) akuntabilitas kebijakan; dan memiliki hak dan

(5) akuntabilitas finansial. pertanggungjawaban

Transparansi penjelasan manajemen organisasi indikator yang dikembangkan sector public tentang aktivitas, oleh (Ultafiah, 2017) program dan kebiajkan yang sudah, Indikator pengukuran variabel sedang dan akan dilakukan beserta transparansi antara lain: sumber daya yang akan (1) formatif; digunakannya(Mahmudi, 2015)

(2) keterbukaan; dan

(3) pengungkapan.

Partisipasi Masyarakat keterlibatan masyarakat dalam pembuatan keputusan baik secara langsung maupun tidak langsung melalui lembaga perwakillan yang dapat menyalurkan aspirasinya.
Adapun indikator pengukuran variabel partisipasi masyarakat yaitu,

(1) pengambilan keputusan;

(2) pelaksanaan;

(3) pengambilan manfaat; dan

(4) evaluasi.

Sumber: Data Penelitian 2021

Analisis tersebut digunakan untuk mengetahui efek interaksi antara variabel akuntabilitas, transparansi dan partisipasi masyarakat terhadap pengelolaan alokasi dana desa. Alat analisis yang digunakan dalam penelitian ini 
adalah SPSS 17. Adapun persamaan model regresi secara sistematis sebagai berikut:

$\mathrm{Y}=\mathrm{a}+\mathrm{b} 1 \mathrm{X} 1+\mathrm{b} 2 \mathrm{X} 2+\mathrm{b} 3 \mathrm{X} 3+\varepsilon$

Keterangan :

Y = Pengelolaan Alokasi Dana Desa

a $\quad=$ Konstanta

b1-b7 = Koefisien Regresi

$\mathrm{X} 1=$ Akuntabilitas

$\mathrm{X} 2=$ Transparansi

$\mathrm{X} 3=$ Partisipasi Masyarakat

$\varepsilon \quad=$ Error

\section{HASIL DAN PEMBAHASAN}

Populasi penelitian ini adalah 27 desa yang ada di kecamatan labuapi dan lingsar yang berasal dari kepala desa, sekretaris desa, aparat desa, dan seksi alokasi dana desa. Sampel responden ditetapkan secara non probability sampling yaitu purposive sampling yaitu berdasarkan pertimbangan dapat memberikanin formasi yang diperlukan. Jumlah ditetapkan 27 desaatau 108 responden yang terdiri dari kepala desa, sekertaris desa, bendahara desa, dan seksi alokasi dana desa di Kabupaten Lombok Barat. Hasil dari kuisioner yang kita sebarkan dengan membagikan ke setiap kantor desa yang ada di kec. Lingsar dan labu api. Sebagian besar responden dis etiap desa ada yang langsung mengisi angket yang telah disediakan.

Tabel 2. Tingkat Pengembalian Kuesioner Menurut Persentase ( \% )

\begin{tabular}{lll}
\hline \multirow{2}{*}{ Keterangan } & \multicolumn{2}{c}{ Responden } \\
\cline { 2 - 3 } & Jumlah & $\%$ \\
\hline Kuesioneryang disebarkan & 108 & $100 \%$ \\
Kuesioneryang kembali & 95 & $87,96 \%$ \\
Kuesioneryang tidak dapat diolah & 5 & $4,63 \%$ \\
Kuesioneryang dapat diolah & 90 & $83,33 \%$ \\
\hline
\end{tabular}

Sumber: Data Penelitian, 2021

Pengujian validitas dilakukan dengan melihat nilai Corrected Item-Total Correlation. Jika nilai rhitung positif dan lebih besar dari rtabel (pada taraf signifikansi $5 \%$ atau 0,05$)$, maka data dapat dikatakan valid.

Tabel 3. Hasil Uji Validitas Variabel Akuntabilitas

\begin{tabular}{lccc}
\hline Item & r hitung & r tabel & Keterangan \\
\hline 1 & 0,764 & 0,198 & Valid \\
2 & 0,668 & 0,198 & Valid \\
3 & 0,751 & 0,198 & Valid \\
4 & 0,765 & 0,198 & Valid \\
5 & 0,473 & 0,198 & Valid \\
6 & 0,610 & 0,198 & Valid \\
\hline
\end{tabular}

Sumber: Data Penelitian2021

Tabel 3 menunjukkan item pertanyaan kuesioner pada variabel akuntabilitas memiliki nilai rhitung $>$ rtabel dan juga bernilai positif dengan taraf signifikan 0,05 , berarti data dari instrumen untuk variabel akuntabilitas dikatakan valid. 
Tabel 4. Hasil Uji Validitas Variabel Partisipasi Masyarakat

\begin{tabular}{lccc}
\hline Item & r hitung & r table & Keterangan \\
\hline 1 & 0,499 & 0,198 & Valid \\
2 & 0,475 & 0,198 & Valid \\
3 & 0,716 & 0,198 & Valid \\
4 & 0,087 & 0,198 & Valid \\
5 & 0,637 & 0,198 & Valid \\
6 & 0,720 & 0,198 & Valid \\
7 & 0,566 & 0,198 & Valid \\
\hline
\end{tabular}

Sumber: Data Penelitian2021

Tabel 4 menunjukkan item pertanyaan kuesioner pada variabel partisipasi masyarakat memiliki nilai rhitung > rtabel dan juga bernilai positif dengan taraf signifikan 0,05, berarti data dari instrumen untuk variabel partisipasi masyarakat dikatakan valid.

\begin{tabular}{lccc}
\multicolumn{4}{l}{ Tabel 5. Hasil Uji Validitas Variabel Pengelolaan Alokasi Dana Desa } \\
\hline Item & r hitung & r table & Keterangan \\
\hline 1 & 0,656 & 0,198 & Valid \\
2 & 0,678 & 0,198 & Valid \\
3 & 0,638 & 0,198 & Valid \\
4 & 0,637 & 0,198 & Valid \\
5 & 0,738 & 0,198 & Valid \\
6 & 0,738 & 0,198 & Valid \\
7 & 0,785 & 0,198 & Valid \\
8 & 0,625 & 0,198 & Valid \\
9 & 0,694 & 0,198 & Valid \\
\hline
\end{tabular}

Sumber: Data Penelitian2021

Berdasarkan Tabel 5 menunjukkan item pertanyaan kuesioner pada variabel pengelolaan alokasi dana desa memiliki nilai rhitung>rtabel dan juga bernilai positif dengan taraf signifikan 0,05 , berarti data dari instrumen untuk variabel pengelolaan alokasi dana desa dikatakan valid. Uji reliabilitas menggunakan uji statistik Cronbatch Alpha (a). Suatu item kuesioner dikatakan reliable apabila nilai Cronbatch Alpha $>0,60$

Tabel 6. Hasil Uji Reliabilitas

\begin{tabular}{lcc}
\hline Variabel & Cronbatch Alpha & Keterangan \\
\hline Akuntabilitas & 0,886 & Reliabel \\
Transparansi & 0,931 & Reliabel \\
Partisipasi Masyarakat & 0,880 & Reliabel \\
& 0,928 & Reliabel \\
\hline
\end{tabular}

Sumber: Data Penelitian2021

Berdasarkan Tabel 6, diketahui bahwa nilai Cronbatch Alpha untuk masing - masing variabel adalah untuk akuntabilitas 0,886, transparansi 0,931, partisipasi masyarakat sebesar 0,880 , dan pengelolaan alokasi dana desa 0,928; artinya data untuk semua variabel ini lebih besar dari 0,60, dan dapat disimpulkan bahwa semua variabel pada penelitian ini dapat dikatakan reliabel.

Hasil penelitian ini menunjukkan bahwa transparansi memberikan dampak positif terhadap pengelolaan alokasi dana desa atau berpengaruh positif terhadap pengelolaan alokasi dana desa di kecamatan labuapi dan lingsar kabupaten lombok barat. Proses transparansi keuangan desa salah satu tolak ukur 
demi kelancaran suatu program yang ada di desa tersebut sebab penggunaan keuangan desa harus diketahui oleh masyarakat desa sehingga lancarnya pengelolaan alokasi dana desa harus didasari dengan prinsip transparansi.

Tabel 7. Hasil Uji Hipotesis (Uji t) Coefficients

\begin{tabular}{lccccc}
\hline Model & \multicolumn{2}{c}{ Unstandardized Coefficients } & \multirow{2}{*}{ t } & Sig. \\
\cline { 2 - 3 } & $\mathrm{B}$ & Std. Error & & & \\
\hline (Constant) & 3,295 & 3,551 & & 0,928 & 0,359 \\
Transparansi & 0,390 & 0,087 & & 4,460 & 0,000 \\
Partisipasi Masyarakat & 0,003 & 0,049 & & 0,066 & 0,947 \\
Akuntabilitas & 0,917 & 0,108 & & 8,490 & 0,000 \\
& & & & &
\end{tabular}

a. Dependent Variable: Pengelolaan Alokasi Dana Desa

Sumber: Data Penelitian 2021

Dimana hasil penelitian Variabel transparansi memiliki nilai thitung sebesar 4,460 lebih besar dari tabel 2,019 atau nilai sig sebesar 0,000 kecil dari 0,05, artinya $\mathrm{H} 0$ ditolak dan $\mathrm{H} 1$ diterima, bahwa transparansi berpengaruh positif dan signifikan terhadap pengelolaan alokasi dana desa di kecamatan labuapi dan lingsar Kabupaten Lombok Barat. Namun hasil dari Variabel transparansi memiliki nilai thitung sebesar 8,490 lebih besar dari ttabel 2,019 atau nilai sig sebesar 0,000 kecil dari 0,05, artinya H0 ditolak dan H3 diterima, bahwa akuntabilitas berpengaruh positif dan signifikan terhadap pengelolaan alokasi dana desa di kecamatan labuapi dan lingsar Kabupaten Lombok Barat. Hasil penelitian menjelakan bahwa transparansi yang di lakukan oleh setiap desa yang ada di kec lingsar dan labu api, sudah seuai dengan prosedur yang ada di peraturan permendagri no 20 tahun 2018 dimana setiap kepala desa melaporkan kegiatan desa bisa melalui madding desa, baliho desa yang menjelaskan kegiatan yang ada.

Tabel 8. Hasil Uji Kelayakan Model (Uji F) ANOVA

\begin{tabular}{lccccc} 
Model & Sum of Squares & df & Mean Square & F & Sig. \\
\hline 1 Regression & 506.666 & 3 & 168.889 & 90.422 & $.000 \mathrm{a}$ \\
Residual & 76.579 & 41 & 1.868 & & \\
Total & 583.244 & 44 & & & \\
\hline
\end{tabular}

a. Predictors: (Constant), Akuntabilitas, Partisipasi Masyarakat, Transparansi

b. Dependent Variable: Pengelolaan Alokasi Dana Desa

Sumber: Data Penelitian 2021

Sedangkan Variabel partisipasi masyarakat memiliki nilai thitung sebesar -0,066 lebih kecil dari ttabel 2,019 atau nilai sig sebesar 0,947 besar dari 0,05, artinya $\mathrm{H} 0$ diterima dan $\mathrm{H} 2$ ditolak, bahwa partisipasi masyarakat berpengaruh positif dan tidak signifikan terhadap pengelolaan alokasi dana desa di kecamatan labuapi dan lingsar Kabupaten Lombok Barat. Hal ini menunjukkan bahwa partisipasi masyarakat tidak memberikan dampak terhadap pengelolaan alokasi dana desa atau tidak berpengaruh terhadap pengelolaan alokasi dana desa di kecamatan labuapi dan lingsar kabupaten lombok barat. Sumber pendapatan desa terdiri dari pendapatan asli desa, dana desa, dan alokasi dana desa, sedangkan 
alokasi dana desa khusus dipergunakan untuk kegiatan operasional pemerintah desa seperti tunjangan tetap perangkat desa dan lain-lain dan untuk dana desa diperuntukkan untuk program pembangunan, pemberdayaan, pembinaan, dan pembiayaan sehingga peran masyarakat sangat penting demi kelancaran program desa sumber alokasi dana desa, sehingga pada penelitian ini alokasi dana desa tidak berpengaruh pada partisipasi masyarakat sebab kegunaan dari alokasi danan desa untuk operasional pemerintah desa.

Hasil penelitian ini menunjukkan bahwa akuntabilitas berpengaruh positif dan signifikan terhadap pengelolaan alokasi dana desa. Hal ini dibuktikan dari hasil kuisioner yang ada yang mejjelaskan setiap bagian yang ada di desa melapokan kegiatan dan melaporkan hasil dari kegiatan yang ada, baik dari hasil laporan kegiatan dipertangung jawabkan ke pemeritahan kabupatten. Untuk mengetahui kinerja dan sistem pemerintahan yang baik dengan mengetahui pertanggung jawaban semua jenis kegiatan yang dilakukan. Pengelolaan alokasi dana desa juga perlu dipertanggung jawabkan sebab Alokasi Dana Desa jangan sampai disalah gunakan oleh pemerintah desa dan dialporkan ke Kabupaten sebagai pertangung jawaban.

\section{SIMPULAN}

Akuntabilitas berpengaruh positif dan signifikan terhadap pengelolaan alokasi dana desa di Kecamatan Labuapi dan Lingsar Pada Kabupaten Lombok Barat. Dimana hasil penelitian ini yang dilakukan dalam penerapan tanggung jawab aparatur desa melakukan tugas nya masing-masing sebagai tugas pokok mereka, sebagai mana kegiatan yang sudah ditetapkan pada saat musrenbang. Dan mereka melaksanakan kegiatan dan melaporkan dengan membuat semacam baliho laporan kegiatan. Ada yang menyajikan laporan kegiatan di taruh di mading desa dan ada juga yang menaruh di tempat kegiatan.

Partisipasi masyarakat berpengaruh positif dan tidak signifikan terhadap pengelolaan alokasi dana desa di Kecamatan Labuapi dan Lingsar Pada Kabupaten Lombok Barat. Karena warga desa hanya mendapatkan laporan secara umum saja tanpa melibatkan warga desa dalam melakukan kegiatan dalam pembaggunan desa hal ini yang menjadi tidak ada peran yang bisa di berikan masyarakat untuk membangun dan mengawasi kegiatan yang ada. Transparansi berpengaruh positif dan signifikan terhadap pengelolaan alokasi dana desa di Kecamatan Labuapi dan Lingsar Pada Kabupaten Lombok Barat. Secara garis besar pelaporan yang dilakukan oleh pemerintahan desa melaporkan dengan menjelaskan laporan selama setahun yang di pajang di setiap masing masing desa dimana dalam laporan yang dijelasakan semacam baliho atau baner anggaran belanja dan anggaran kegiatan.

Penelitian ini memeiliki keterbatasan merupakan kekurangan kekurangan selama proses penelitian. Beberapa keterbatasan dalam penelitian ini antara lain: Data semua variable dalam model diragukan akurasinya, karena sasaranya adalah opini perasaan pribadi responden, bukan data kenyataan hasil praktik dilapangan. Syarat-syarat validitas dan reliabilitas instrument dans yaratsyarat asumsi klasik variable masih sulit terjamin sepenuhnya. Penelitian ini hanya mengandalkan besaran jumlah responden padahal mestinya berdasarkan 
banyaknya observasi (desa). Keterbatasan lain adalah nyaris tidak ada ulasan kuantitatif data, misalnya variable akuntabilitas.

Selama proses penelitian disarankan untuk dapat dipertimbangkan riset mendatang diharapkan dapat menambah beberapa variable yang berpotensi dalam pengelolaan alokasi dana desa seperti Ketua Pelaksana Kegiatan yang berkecimoung langsung dengan kegiatan, BPD (Badan Pengawas Desa) dilibatkan bersama masyarakat untuk sebagai pelaku dari Desa untuk Desa dengan menerapakan kegiatan Padat Karya. Dapat menambah jumlah responden penelitian dan lingkupan penelitian agar bisa menjadi refrensi peneliti selanjutnya yang berkaitan dengan alokasi dana desa. Penelitian selanjutnya diharapkan dapat menggunakan kuesioner yang bersifat terbuka sehingga data yang diperoleh lebih optimal dalam mencerminkan fakta yang terjadi.

\section{REFERENSI}

Andriani, M. (2019). Pengaruh Transparansi, Akuntabilitas, Dan Partisipasi Masyarakat Terhadap Pengelolaan Dana Desa(Studi Pada Desa Luk, Kecamatan Rhee, Kabupaten Sumbawa). Https://Jurnal.Uts.Ac.Id/Index.Php/Jafa/Article/View/323, Vol 1.

Damayanti, Wienda. (2018). Transparansi Dan Akuntabilitas Pemerintah Desa Dalam Pengelolaan Alokasi Dana Desa.

Fahri, S. (2020). Akuntabilitas, Efektivitas Dan Transparansi Pemerintah Desa Terhadap Pengelolaan Dana Desa (Studi Pada Desa Di Kecamatan Ayah Kabupaten Kebumen). Fakultas Ekonomi Dan Bisnis, STIE YKPN.

Faria, J. A. De, \& Maria, S. Da S. (2013). The Effects Of Information Asymmetry On Budget Slack: An Experimental Research. African Journal Of Business Management, 7(13), 1086-1099. Https://Doi.Org/10.5897/AJBM2013.1641

Firdaus, Anita. , Suharno. , Sunarti.,. (2020). Pengaruh Transparansi, Akuntabilitas Dan Partisipasi Masyarakat Terhadap Pengelolaan Alokasi Dana Desa Di Desa Sidoharjo Kecamatan Sidoharjo Kabupaten Sragen. Https://Ejurnal.Unisri.Ac.Id/Index.Php/Akuntansi/Article/View/3692.

Garung, C. Y., \& Ga, L. L. (2020). Pengaruh Akuntabilitas Dan Transparansi Terhadap Pengelolaan Alokasi Dana Desa (Add) Dalam Pencapaian Good Governance Pada Desa Manulea, Kecamatan Sasitamean, Kabupaten Malaka. Maret, 8(1), 19-27. Www.Kupang.Tribunnews.Com

Inside, L. (2020). Salahgunakan-Dana-Desa-Mantan-Kades-Dan-Sekdes-TerongTawah-Jadi-Tersangka/. Inside Lombok.

Kementrian Dalam Negeri. (2018). Permendagri 20 Tahun 2018.

Kementrian Keuangan. (2017). Buku Pintar Dana Desa.

Kementrian Keuangan. (2020). Hasil Dana Desa Sejak 2015. Https:/ / Www.Kemenkeu.Go.Id/ Publikasi/ Berita/Ini-Hasil-Dana-DesaSejak-2015/.

Madiasmo. (2018). Otonomi Dan Manajemen Keuangan Daerah. Andi.

Mahmudi. (2015). Manajemen Kinerja Sektor Publik (3rd Ed.). UPP STIM YKPN.

Mardiasmo. (2009). Akuntansi Sektor Publik (IV). ANDI OFFSET.

Putra, C. K., Pratiwi, R. N., \& Suwondo. (2013). Pengelolaan Alokasi Dana Desa Dalam Pemberdayaan Masyarakat Desa (Studi Pada Desa Wonorejo 
Kecamatan Singosari Kabupaten Malang) . Jurnal Administrasi Publik (JAP), Vol. 1, No. 6, 1203-1212.

Rakyat, D. Perwakilan. , \& Presiden. (2014). UU No 62014.

Republik Indonesia. (2014). Peraturan Pemerintah Republik Indonesia Nomor 6 Tahun 14 Tentang Desa.

Sirajudin, M. H. (2019). Pengaruh Akuntabilitas Terhadap Pengelolaan Dana Desa Dalam Mewujudkan Good Governance.

Solekhan, M. (2014). Penyelenggaraan Pemerintahan Desa Berbasis Partisipasi Masyarakat (1st Ed., Vol.1). Setara Press.

Sukmawati, F., \& Nurfitriani, A. (2019). Pengaruh Transparansi Dan Akuntabilitas Terhadap Pengelolaan Keuangan Desa (Studi Pada Pemerintah Desa Di Kabupaten Garut). In Jurnal Ilmiah Bisnis, Pasar Modal, Dan UMKM (Vol. 2, Issue 1).

Ultafiah, W. (2017). Pengaruh Akuntabilitas, Transparansi Dan Partisipasi Terhadap Pengelolaan

Dana

Desa Untuk Mewujudkan Good Governance Pada Desa Di Kecamatan Merapi Barat Kabupaten Lahat.

Umami, R., \& Nurodin, I. (2017). Pengaruh Transparansi Dan Akuntabilitasterhadap Pengelolaan Keuangan Desa. Jurnal Ilmiah Ilmu Ekonomi, 6, 74-80.

Wahyuni Nur, S. (2019). Peningkatan Transparansi, Akuntabilitas, Dan Partisipatif Melalui Pengelolaan Alokasi Dana Desa Di Desa Tellumpanuae Kabupaten Maros. 3(1), 2598-7984. 